\title{
Pengaruh Program "Social Enterpreneurship" Kelompok ODHA Terhadap Stigma Masyarakat Tentang HIV/AIDS Di Daerah Binaan KPA Kota Kediri.
}

\author{
(Influence Program "Social Enterpreneurship" group ODHA with HIV Stigma Against \\ People About HIV / AIDS In Local Patronage KPA Kediri.)
}

Siti Asiyah, Susanti Pratamaningtyas, Suwoyo

Prodi Kebidanan Kediri Jl.KH.Wakhid Hasyim 64 B Kediri

\begin{abstract}
Sixth goal in the MDGs are handle a variety of the most dangerous infectious diseases. At the top is intended to handle HIV, the virus that causes AIDS. The disease is a devastating impact not only on public health but also to the overall state. This study aims to look at the effect of social entrepreneurship program for public stigma about HIV / AIDS. Analytical research design using cross sectional correlational techniques. The study population is the ODHA, which had already independently of 50 people. Samples were taken by simple random sampling technique, a number of 44 people. Statistical analysis was performed with $\mathrm{Chi}$ Square at alpha 0.05. The result showed that, social entrepreneurship programs that are run by people living with HIV have not succeeded run and people living with HIV is almost entirely feel the stigma which is given by the society. Chi Square Results obtained Alpha 0:00 less than Alpha 0.05. This means that, the Social Entrepreneurship Program affect the public stigma about HIV / AIDS. The results of the study can be used to support the Government's program to empower of ODHA.
\end{abstract}

Keywords: Social entrepreneurship, Stigma, ODHA

\section{PENDAHULUAN}

Tujuan ke enam dalam MDGs yaitu menangani berbagai penyakit menular paling berbahaya. Pada urutan teratas ditujukan untuk menangani HIV yaitu virus penyebab AIDS. Penyakit ini membawa dampak yang menghancurkan bukan hanya terhadap kesehatan masyarakat namun juga terhadap Negara. Oleh karena itu, Masalah penanggulangan dan pencegahan HIV/AIDS harus diyakini merupakan tanggungjawab bersama. Apabila tidak ditangani dengan serius masalah ini dapat mengganggu bahkan mengancam ketenteraman hidup bangsa Indonesia

Di Indonesia, jumlah penduduk yang hidup yang hidup dengan virus HIV diperkirakan antara 172.000 219.000,sebagian besar adalah laki-laki. Jumlah ini merupakan $0,1 \%$ dari jumlah penduduk. Menurut Komisi Penanggulangan AIDS Nasional (KPA), sejak 1987 sampai 2008 , tercatat 12.686 kasus AIDS, 2479 diantaranya telah meninggal. Kalopun kemudian dengan pengobatan yang baik, penderita dapat melanjutkan kehidupan, persoalan tidak kemudian menjadi selesai bagi ODHA. Ketika mereka berada di masyarakat, Stigma masih menjadi persoalan yang banyak terjadi.

Masyarakat relative masih mudah memberikan cap atau sebutan kepada seseorang yang diduga mengidap suatu penyakit yang berbahaya atau menular tanpa berupaya menyelidiki kebenarannya. Faktor-faktor yang mempengaruhi Stigma antara lain bahwa masyarakat masih menganggap HIV/AIDS adalah penyakit yang mengancam hidup, ketakutan untuk kontak dengan HIV, hubungan HIV/AIDS dengan perilaku seperti homoseksual, IDU, PSK dan sebagainya, ODHA dinilai sebagai penyakit yang dibuat sendiri, religi atau kepercayaan yang menyamakan penyakit ini dengan kesalahan moral, 
seperti penyimpangan seks yang pantas mendapat hukuman, status social ekonomi, usia dan gender.

Dampak stigma yang masih kuat di masyarakat pada akhirnya akan menyebabkan perubahan mengenai bagaimana seseorang dipandang oleh orang lain, penolakan social atau penurunan penerimaan dalam interaksi social, keterbatasan/ kehilangan kesempatan seperti misalnya tempat tinggal, pekerjaan, akses terhadap pelayanan kesehatan, perasaan malu dan benci terhadap diri sendiri, menurunkan kualitas hidup seseorang, meningkatkan deskriminasi, menambah beban ganda keluarga serta dapat menghambat upaya pencegahan dan perawatan.

Berdasarkan survei Dampak Sosial Ekonomi pada Individu dan Rumah Tangga dengan HIV di Tujuh Provinsi di Indonesia, didapatkan hasil bahwa rerata hilangnya pendapatan akibat merawat anggota rumah tangga yang sakit, 55\% lebih tinggi pada rumah tangga ODHA dibanding rumah tangga non ODHA. 74\% Menyatakan adanya tambahan pengeluaran akibat infeksi HIV. Rumah Tangga ODHA mengeluarkan biaya kesehatan 5 kali lebih tinggi dari Rumah Tangga Non-ODHA. Rerata biaya kesehatan ODHA sendiri 3 kali lebih tinggi dari Rumah Tangga Non-ODHA.

Dari data di atas dapat diketahui bahwa ODHA dan keluarga ODHA akan menghadapi beban ganda, baik sosial maupun ekonomi, meskipun mereka masih mendapat obat ARV gratis dari bantuan pemerintah, namun masih banyak pengeluaran yang dibutuhkan oleh ODHA dan keluarganya. Kebijakan nasional penanggulangan HIV dan AIDS menggarisbawahi kebutuhan serangkaian program layanan yang komprehensif dan bermutu yang menjangkau luas masyarakat dengan tujuan mencegah dan mengurangi penularan HIV, meningkatkan kualitas hidup ODHA dan mengurangi dampak sosial dan ekonomi akibat HIV dan AIDS pada individu, keluarga dan masyarakat.

Berbagai cara dapat dilakukan untuk mengatasi masalah stigma di masyarakat berkaitan dengan HIV/AIDS, diantaranya di pelayanan kesehatan dapat dilakukan dengan cara: membantu penderita untuk mengatasi ketakutan terhadap status HIV/AIDS, mengajarkan ketrampilan dalam menangani penderita, sedangkan dimasyarakat dapat dilakukan upaya melibatkan tokoh masyarakat dalam memasyarakatkan anti stigma. Dengan upaya-upaya ini, maka diharapkan para penderita HIV/AIDS dapat diterima di masyarakat dan dapat diberdayakan untuk memandirikan mereka melalui kegiatankegiatan social entrepreneurship (Kewirausahaan Sosial).

Social Entrepreneurship akhir-akhir ini menjadi makin popular. Namun di Indonesia sendiri kegiatan ini masih belum mendapatkan perhatian yang sungguh sungguh dari pemerintah dan para tokoh masyarakat karena memang belum ada keberhasilan yang menonjol secara nasional. Pengertian sederhana dari Social Entrepreneur adalah seseorang yang mengerti permasalahan sosial dan menggunakankemampuan entrepreneursh ip untuk melakukan perubahan sosial (social change), terutama meliputi bidang kesejahteraan (welfare), pendidikan dan kesehatan (healthcare). Keberhasilan Sosial Entrepreneurship diukur dari manfaat yang dirasakan oleh masyarakat.

Pemberdayaan ODHA/OHIDHA diyakini merupakan salah satu kunci bagi penanggulangan dan pencegahan HIV/AIDS. Program pemberdayaan yang tepat dalam hal ini sangat dibutuhkan (Rima Jauharoh, 2011). Program pemberdayaan merupakan langkah yang positif oleh karena dapat menjawab kebutuhan sehingga para penderita HIV/AIDS akan mengalami perubahanperubahan yang positif dan pada akhirnya turut pula meningkatkan mutu hidup ODHA. Program pemberdayaan untuk ODHA sejalan dengan prinsip 
dasar andragogy di mana program pemberdayaan tersebut dipandang oleh ODHA sebagai program pemberdayaan yang partisipatif dan menempatkan ODHA sebagai subyek bukan obyek sehingga mereka dapat terlibat dalam upaya pencegahan dan penanggulangan HIV/AIDS. Dengan demikian perlu diadakan penelitian untuk melihat Pengaruh Program Sosial Enterpreneurship pada ODHA terhadap Stigma masyarakat tentang HIV/AIDS.

\section{Metode Penelitian}

Desain yang digunakan dalam penelitian ini adalah analitik korelasional, yaitu melihat pengaruh Program Sosial Enterpreneurship pada ODHA terhadap Stigma masyarakat tentang HIV/AIDS. Pendekatan waktu yang digunakan adalah cross sectional.

Populasi dalam penelitian ini adalah semua ODHA yang sudah mandiri dan menjadi binaan dari KPA Kota Kediri. Sampel penelitian ini adalah sebagian ODHA yang sudah mandiri dan menjadi binaan dari KPA Kota Kediri yang diambil dengan simple random sampling. Besar sampel ditentukan dengan penghitungan sbb:

$$
\mathrm{n}=\frac{\mathrm{N}}{1+\mathrm{N}(\mathrm{d})^{2}}
$$

Keterangan:

$\mathrm{n} \quad=$ besar sampel

$\mathrm{d}=$ Tingkat significansi (0.05)

$\mathrm{N}=$ Besar populasi

Dengan Jumlah Populasi sebesar 50, maka besar sampel yang dibutuhkan adalah:

$\mathrm{n}=\frac{50}{1+50(0.05)^{2}}$
$\mathrm{n}=\frac{50}{1,125}$
$=44$ orang

Jurnal Ilmu Kesehatan Vol. 3 No. 2 Mei 2015
Jadi sampel penelitian ini adalah 44 orang dengan ODHA

Kriteria Inklusi untuk ODHA:

1. Berada di wilayah binaan KPA Kota Kediri

2. Menjalankan Usaha sebagai bentuk program social enterpreneurship

3. Dapat membaca dan menulis

4. Bersedia menjadi responden

Tempat Penelitian: Penelitian dilaksanakan di daerah Binaan KPA Kota Kediri Waktu Penelitian : Dilakukan pada bulan Agustus 2014. Variabel Penelitian: Variabel bebas dalam penelitian ini adalah Program Social Enterpreneurship dan Variabel tergantungnya adalah Persepsi ODHA tentang Stigma HIV/AIDS di masyarakat

Untuk menganalisa pengaruh Program Sosial Enterpreneurship pada ODHA terhadap Stigma Masyarakat tentang HIV/AIDS dilakukan uji Chi Square dengan $\alpha 0,05$.

\section{HASIL PENELITIAN}

Data Umum

1. Umur Responden

Tabel 1 Umur Responden Pengaruh Program Sosial Enterpreneurship Kelompok ODHA terhadap Stigma Masyarakat tentang HIV AIDS

\begin{tabular}{|c|c|c|}
\hline UMUR & $\sum$ & $\%$ \\
\hline $20-35$ & 24 & 54.5 \\
\hline$>35$ & 20 & 45.5 \\
\hline JUMLAH & 44 & 100 \\
\hline
\end{tabular}

Dari tabel di atas, tampak bahwa Responden ODHA pada penelitian ini $54,5 \%$ berumur $20-35$ tahun.

2. Pendidikan

Tabel 2 Pendidikan Responden Pengaruh Program Sosial Enterpreneurship Kelompok ODHA terhadap Stigma Masyarakat tentang HIV AIDS

\begin{tabular}{|c|c|c|}
\hline PENDIDIKAN & $\sum$ & \% \\
\hline Dasar & 11 & 25.0 \\
\hline Menengah & 22 & 50.0 \\
\hline Perguruan Tinggi & 11 & 25.0 \\
\hline JUMLAH & 44 & 100 \\
\hline
\end{tabular}

Dari tabel di atas, tampak bahwa setengah Responden ODHA pada 
penelitian ini berpendidikan menengah (SMA) .

3. Jenis Kelamin

Tabel 3 Jenis kelamin Responden penelitian Pengaruh Program Sosial Enterpreneurship Kelompok ODHA terhadap Stigma Masyarakat tentang HIV AIDS

\begin{tabular}{|c|c|c|}
\hline $\begin{array}{c}\text { JENIS } \\
\text { KELAMIN }\end{array}$ & $\sum$ & $\%$ \\
\hline Laki-laki & 23 & 52.3 \\
\hline Perempuan & 21 & 47.7 \\
\hline JUMLAH & 44 & 100 \\
\hline
\end{tabular}

Dari tabel di atas, tampak bahwa Jenis Kelamin Responden ODHA pada penelitian ini hampir berimbang antara yang berjenis kelamin laki-laki dan perempuan.

\section{Pekerjaan}

Tabel 4 Pekerjaan Responden penelitian Pengaruh Program Sosial Enterpreneurship Kelompok ODHA terhadap Stigma Masyarakat tentang HIV AIDS

\begin{tabular}{|c|c|c|}
\hline PEKERJAAN & $\sum$ & $\%$ \\
\hline Petani & 2 & 4.5 \\
\hline Wiraswasta & 42 & 95.5 \\
\hline JUMLAH & 44 & 100 \\
\hline
\end{tabular}

Dari tabel di atas, tampak bahwa Pekerjaan Responden ODHA pada penelitian ini $95,5 \%$ bekerja di sektor wiraswasta

Data Khusus

1. Jenis Kegiatan Usaha Sosial Enterpreneurship Yang Dijalankan Odha Tabel 5 Rincian usaha yang dijalankan Responden penelitian Pengaruh Program Sosial Enterpreneurship Kelompok ODHA terhadap Stigma Masyarakat tentang HIV AIDS
Dari tabel 5, jika dirinci bidang usaha yang dijalankan didapatkan data sbb:

\begin{tabular}{|c|c|c|}
\hline JENIS USAHA & $\sum$ & $\%$ \\
\hline Pertanian & 2 & 4,5 \\
\hline Catering & 5 & 11,4 \\
\hline Toko kelontong & 8 & 18,2 \\
\hline Jualan Pakaian & 2 & 4,5 \\
\hline Menjahit & 2 & 4,5 \\
\hline Lain-lain & 25 & 56,9 \\
\hline JUMLAH & 44 & 100 \\
\hline
\end{tabular}

Dari tabel di atas, tampak bahwa jenis usaha yang paling banyak dikerjakan oleh Responden ODHA pada penelitian ini adalah bidang wirausaha lainnya seperti model, jual bakso, bakpau, laundry, beternak ayam dll. Dari jenis usaha/jenis kegiatan yang dijalankan ODHA diatas, terdapat beberapa hal yang dapat menjadi penghambat dan pendukung dalam mengembangkan usaha para ODHA yaitu:

1.a. Kesesuaian Minat Dan Bakat Dengan Usaha Yang Dijalankan

Tabel 6 Minat ODHA dalam menjalankan Program Sosial Enterpreneurship

\begin{tabular}{|c|c|c|}
\hline $\begin{array}{c}\text { MINAT DAN } \\
\text { BAKAT }\end{array}$ & $\sum$ & $\%$ \\
\hline Sesuai & 40 & 90.9 \\
\hline Tidak Sesuai & 4 & 9.1 \\
\hline JUMLAH & 44 & 100 \\
\hline
\end{tabular}

Dari tabel 6 dapat dilihat bahwa usaha yang dijalankan oleh ODHA saat ini 90,9\% sesuai dengan minat dan bakat para ODHA.

1.b. Kecocokan Bidang Usaha Yang Dijalankan

Tabel 7 Kecocokan bidang usaha yang dijalankan para ODHA

\begin{tabular}{|c|c|c|}
\hline KECOCOKAN & $\sum$ & $\%$ \\
\hline Cocok & 40 & 90.9 \\
\hline Tidak Cocok & 4 & 9.1 \\
\hline JUMLAH & 44 & 100 \\
\hline
\end{tabular}

Dari tabel 7 dapat dilihat bahwa 90,9\% ODHA merasa cocok dengan usaha yang dijalankan saat ini. Dan hanya 4 orang saja yang merasa tidak cocok dengan usahanya saat ini. 
1.c. Pemenuhan Kebutuhan Hidup Dari Usaha Yang Dijalankan

Tabel 8 Pemenuhan kebutuhan Hidup para ODHA dari usaha yang dijalankan

\begin{tabular}{|c|c|c|}
\hline $\begin{array}{c}\text { PEMENUHAN } \\
\text { KEBUTUHAN } \\
\text { HIDUP }\end{array}$ & $\sum$ & $\%$ \\
\hline Terpenuhi & 32 & 72.7 \\
\hline Tidak Terpenuhi & 12 & 27.3 \\
\hline JUMLAH & 44 & 100 \\
\hline
\end{tabular}

Dari tabel di atas, dapat disimpulkan bahwa lebih dari separo $(72,7 \%)$ ODHA dapat memenuhi kebutuhan hidupnya dari usaha yang selama ini di jalankan.

\section{1.d. Kendala Dalam Menekuni Usaha}

Tabel 9 Kendala para ODHA dalam menekuni usaha

\begin{tabular}{|c|c|c|}
\hline $\begin{array}{c}\text { KENDALA } \\
\text { DALAM USAHA }\end{array}$ & $\sum$ & $\%$ \\
\hline Ada & 21 & 47.7 \\
\hline Tidak ada & 23 & 52.3 \\
\hline JUMLAH & 44 & 100 \\
\hline
\end{tabular}

Berdasar tabel 9 dapat disimpulkan bahwa jumlah ODHA yang mengatakan tidak ada kendala dalam menekuni usahanya, sedikit lebih banyak dari pada yang merasakan kendala

\section{1.e. Penyebab Hambatan}

Tabel 10 Penyebab hambatan dalam menjalankan usaha

\begin{tabular}{|c|c|c|}
\hline $\begin{array}{c}\text { PENYEBAB } \\
\text { HAMBATAN }\end{array}$ & $\sum$ & $\%$ \\
\hline Kurang Modal & 38 & 86.4 \\
\hline Lain-lain & 6 & 13.6 \\
\hline JUMLAH & 44 & 100 \\
\hline Berdasar tabel 4.10, dapat
\end{tabular}

disimpulkan bahwa hambatan terbesar para ODHA dalam menjalankan usaha adalah kurangnya modal $(86,4 \%)$

\section{1.f. Pengaruh Hambatan}

Tabel 11 Pengaruh hambatan dalam pengembangan usaha

\begin{tabular}{|c|c|c|}
\hline $\begin{array}{c}\text { PENGARUH } \\
\text { HAMBATAN } \\
\text { THD USAHA }\end{array}$ & $\sum$ & $\%$ \\
\hline Berpengaruh & 33 & 75.0 \\
\hline Tidak berpengaruh & 11 & 25.0 \\
\hline JUMLAH & 44 & 100 \\
\hline
\end{tabular}

Berdasar tabel di atas, dapat disimpulkan bahwa $3 / 4 \quad$ ODHA mengungkapkan bahwa adanya hambatan berpengaruh terhadap pengembangan usaha

\section{1.g. Cara Mengatasi Hambatan}

Tabel 12 Cara ODHA mengatasi hambatan dalam Usaha yang dijalankan

\begin{tabular}{|c|c|c|}
\hline $\begin{array}{c}\text { CARA } \\
\text { MENGATASI } \\
\text { HAMBATAN }\end{array}$ & $\sum$ & $\%$ \\
\hline Cari pinjaman & 21 & 47.7 \\
\hline Berkonsultasi & 10 & 22.7 \\
\hline $\begin{array}{c}\text { Pendekatan pada } \\
\text { masyarakat }\end{array}$ & 8 & 18.2 \\
\hline Lainnya & 5 & 11.4 \\
\hline JUMLAH & 44 & 100 \\
\hline
\end{tabular}

Dari tabel 12 diketahui, bahwa solusi terbanyak yang dipilih oleh ODHA untuk mengatasi hambatan yang ada dalam mengembangkan usaha adalah dengan mencari pinjaman, di susul dengan berkonsultasi kepada pihak yang kompeten.

\section{1.h. Dukungan Keluarga}

Tabel 13 Dukungan Keluarga dalam menjalankan usaha

\begin{tabular}{|c|c|c|}
\hline $\begin{array}{c}\text { DUKUNGAN } \\
\text { KELUARGA }\end{array}$ & $\sum$ & $\%$ \\
\hline Ada & 43 & 97.7 \\
\hline Tidak ada & 1 & 2,3 \\
\hline JUMLAH & 44 & 100 \\
\hline Dari tabel 13 diketahui, bahwa
\end{tabular}
hampir seluruh ODHA mendapatkan dukungan dari keluarga dalam mengembangkan usaha

1.i. Penerimaan Masyarakat Terhadap Usaha Yang Dijalankan

Tabel 14 Penerimaan Masyarakat terhadap usaha yang dijalankan ODHA

\begin{tabular}{|c|c|c|}
\hline $\begin{array}{c}\text { PENERIMAAN } \\
\text { MASYARAKAT }\end{array}$ & $\sum$ & $\%$ \\
\hline Diterima & 44 & 100.0 \\
\hline Tidak Diterima & 0 & 0 \\
\hline JUMLAH & 44 & 100 \\
\hline
\end{tabular}

Dari tabel 14, dapat dilihat bahwa seluruh masyarakat dapat menerima dengan baik usaha-usaha yang dilakukan oleh ODHA 
1.j. Bantuan Organisasi Kemasyarakatan Tabel 15 Bantuan dari Organisasi Kemasyarakatan untuk mengembangkan Usaha para ODHA

\begin{tabular}{|c|c|c|}
\hline $\begin{array}{c}\text { BANTUAN DARI } \\
\text { ORMAS }\end{array}$ & $\sum$ & $\%$ \\
\hline Ada & 9 & 20.5 \\
\hline Tidak Ada & 35 & 79.5 \\
\hline JUMLAH & 44 & 100 \\
\hline
\end{tabular}

Dari tabel 15, dapat dilihat bahwa lebih dari separo $(79,5 \%)$ ODHA mengungkapkan bahwa mereka tidak mendapat bantuan dari organisasi Kemasyarakatan dalam mengembangkan usaha

1.k. Dampak Usaha Untuk Meningkatkan Kepercayaan Diri

Tabel 16 Dampak Usaha untuk Kepercayaan diri para ODHA

\begin{tabular}{|c|c|c|}
\hline $\begin{array}{c}\text { KEPERCAYAAN } \\
\text { DIRI }\end{array}$ & $\sum$ & $\%$ \\
\hline Ada & 43 & 97.7 \\
\hline Tidak Ada & 1 & 2,3 \\
\hline JUMLAH & 44 & 100 \\
\hline
\end{tabular}

Dari tabel 16, dapat dilihat bahwa hamper seluruh ODHA menyatakan bahwa usaha yang mereka jalani meningkatkan kepercayaan diri para ODHA

\subsection{Jalinan Kemitraan}

Tabel 17 Jalinan Kemitran yang di miliki para ODHA

\begin{tabular}{|c|c|c|}
\hline $\begin{array}{c}\text { MENJALIN } \\
\text { KEMITRAAN }\end{array}$ & $\sum$ & $\%$ \\
\hline Ya & 32 & 72.7 \\
\hline Tidak & 12 & 27.3 \\
\hline JUMLAH & 44 & 100 \\
\hline
\end{tabular}

Dari tabel 17, dapat disimpulkan bahwa 72,7 \% ODHA menjalin kemitraan dengan pihak lain dalam mengembangkan usaha

1.m. Pelatihan Untuk Pengembangan Usaha

Tabel 18 Pelatihan yang di ikuti para ODHA

\begin{tabular}{|c|c|c|}
\hline PELATIHAN & $\sum$ & $\%$ \\
\hline Ya & 12 & 27.3 \\
\hline Tidak & 32 & 72.7 \\
\hline JUMLAH & 44 & 100 \\
\hline
\end{tabular}

Dari tabel 18, dapat disimpulkan bahwa 72,7 \% ODHA belum pernah mengikuti pelatihan yang relevan dengan bidang usaha yang dijalankan

1.n. Peran Lsm

Tabel 19 Peran LSM bagi para ODHA

\begin{tabular}{|c|c|c|}
\hline PERAN LSM & $\sum$ & $\%$ \\
\hline Ya & 22 & 50.0 \\
\hline Tidak & 22 & 50.0 \\
\hline JUMLAH & 44 & 100 \\
\hline
\end{tabular}

Dari tabel 19, dapat disimpulkan bahwa ODHA yang mengungkapkan bahwa LSM berperan bagi ODHA dan yang menjawab tidak berperan dalam pengembangan ODHA adalah sama besarnya $(50 \%)$

2. Keberhasilan Program Sosial Enterpreneurship

Tabel 20 Keberhasilan Program Sosial Enterpreneurship yang dijalankan pada Kelompok ODHA

\begin{tabular}{|c|c|c|}
\hline $\begin{array}{c}\text { KEBERHASILAN } \\
\text { PROGRAM }\end{array}$ & $\sum$ & $\%$ \\
\hline Berhasil & 5 & 11,4 \\
\hline Tidak Berhasil & 39 & 88,6 \\
\hline JUMLAH & 44 & 100 \\
\hline
\end{tabular}

Dari tabel di atas, tampak bahwa Program Sosial Enterpreneurship yang dijalankan ODHA pada penelitian ini $88,6 \%$ berada pada kategori tidak berhasil

3. Stigma Masyarakat Tentang Hiv/Aids Tabel 21 Stigma masyarakat tentang HIV/AIDS berdasar persepsi dari para ODHA

\begin{tabular}{|c|c|c|}
\hline STIGMA & $\sum$ & \% \\
\hline Ada & 40 & 90,9 \\
\hline Tidak Ada & 4 & 9,1 \\
\hline JUMLAH & 44 & 100 \\
\hline
\end{tabular}

Dari tabel di atas, hampir seluruh responden $(90,9 \%)$ mempersepsikan bahwa masyarakat memberikan Stigma (cap buruk) tentang HIV/AIDS 
4. Pengaruh Program Sosial Enterpreneurship Terhadap Stigma Masyarakat Tentang Hiv/Aids

Untuk menganalisa pengaruh Program Sosial Enterpreneurship pada ODHA terhadap Stigma Masyarakat tentang HIV/AIDS dilakukan menggunakan uji Chi Square dengan $\alpha$ 0,05. Dari hasil uji didapatkan $\alpha 0,00(\leq \alpha$ $0,05)$ artinya ada pengaruh program Sosial Enterpreneurship terhadap Stigma masyarakat tentang HIV/AIDS (hasil uji terlampir)

\section{Pembahasan \\ Jenis kegiatan Social Enterpreneurship yang sesuai pada ODHA}

Berdasarkan tabel 4 dan 5, dapat dilihat, bahwa bidang usaha atau jenis kegiatan yang dijalani oleh ODHA adalah pada bidang Wiraswasta. Dengan rincian bidang usaha terbesar adalah pada pilihan lain-lain seperti menekuni dunia modeling, jasa laundry, pedagang bakso dan lain-lain. Jika dikaitkan dengan data yang diperoleh selama penelitian, pilihan bidang kerja ini berkaitan dengan beberapa hal yaitu: dapat dikaitkan dengan umur responden. Sebagian besar responden berusia antara 20- 35 tahun $(54,5 \%)$ dengan pendidikan terakhir terbanyak adalah SMA. Usia ini termasuk ke dalam kelompok usia produktif. Usahausaha yang ditekuni oleh para ODHA, sudah sejalan dengan kebijakan Pemerintah Kota Kediri. Sebagai daerah perkotaan (urban), sektor perdagangan dan jasa di Kota Kediri paling banyak memberikan kesempatan dan lapangan kerja bagi penduduknya. Pengembangan sektor perdagangan dan jasa ini menjadi fokus Pemerintah Kota Kediri dalam mengatasi pengangguran, sebab programprogram pembangunan ekonomi riil di sektor jasa dan perdagangan inilah yang terbukti mampu menggerakkan aktivitas ekonomi masyarakat (LAKIP Kota Kediri, 2013).

Tetapi jika melihat usia tersebut dan dikaitkan dengan penyakit yang dialami maka hal ini tentu merupakan hal yang memprihatinkan. Karena justru di usia yang rata-rata masih muda yang seharusnya mereka memiliki masa depan dan generasi muda yang potensial, mereka harus dihadapkan pada kenyataan bahwa mereka menderita HIV.

Berdasar tabel 3, dapat dilihat bahwa jumlah ODHA laki-laki dan perempuan yang terpilih dalam sampel penelitian ini hampir berimbang. Hal ini dapat dijelaskan, bahwa di kota Kediri jumlah penderita HIV/AIDS tidak lagi didominasi oleh kaum lelaki, tetapi jumlah wanita juga menunjukkan trend meningkat.

Dari jenis kegiatan yang dilakukan oleh para ODHA juga dapat disampaikan hal-hal sbb: bahwa usaha yang digeluti para ODHA sebagian besar sudah sesuai dengan minat dan bakat mereka $(90,9 \%)$, dan mereka merasa cocok menjalankan usaha tersebut. Walaupun usaha yang dijalankan belum besar, para ODHA mengungkapkn bahwa usahanya sudah dapat dipakai untuk memenuhi kebutuhan $(72,7 \%)$. Persoalan hambatan dalam mengembangkan usaha, para ODHA $(47,7 \%)$ mengungkapkan menemui kendala dalam berusaha. Kendala terbesar adalah persoalan modal yang kurang $(86,4 \%)$, dan upaya yang dipilih oleh sebagian besar responden sebagai solusi adalah mencari pinjaman kepada pihak lain atau keluarga. Dukungan keluarga di rasakan hamper seluruh responden $(97,7 \%)$.

Menurut ODHA, dalam mengembangkan usaha, semua masyarakat dapat menerima usaha mereka karena rata2 masyarakat tidak mengetahui bahwa mereka dalah ODHA. Bantuan dari organisasi kemasyarakatn belum dirasakan oleh sebagian responden, begitupun kesempatan untuk mengikuti pelatihan-pelatihan. Sedangkan LSM perannya masih dirasakan oleh separo saja ODHA. 
Stigma Masyarakat tentang HIV/AIDS

Berdasarkan tabel 4. Didapatkan data bahwa 90,9\% responden mempersepsikan bahwa masyarakat memberikan stigma (cap buruk) terhadap penyakit HIV/AIDS. Dan hanya 9,1\% saja yang menganggap masyarakat memperlakukan para ODHA sama dengan orang lain pada umumnya.

Stigma adalah suatu ancaman,sifat dan karakteristik bahwa masyarakat menerima ketidaknyamanan yang sangat tinggi. Mendapat ancaman tersebut membuat seseorang menerima stigmatisasi (Goffman, 1963 dalam Pusdiklat kemenkes, 2013). Stigmatisasi adalah tindakan memfonis seseorang sebagai buruk moral.

Dalam penelitian ini, stigma yang secara umum selalu dirasakan oleh para ODHA diterima dari masyarakat adalah bahwa masyarakat samapai saat ini selalu ketakutan dengan penyakit HIV/AIDS dan akan menghindari jika mengetahui ada penderita HIV/AIDS di sekitarnya. Hal ini sejalan dengan apa yang disampaikan oleh UNAIDS, 2006, bahwa Hukuman sosial atau stigma oleh masyarakat di berbagai belahan dunia terhadap pengidap HIV AIDS terdapat dalam berbagai cara, antara lain tindakan-tindakan pengasingan, penolakan, diskriminasi, dan penghindaran atas orang yang diduga terinfeksi HIV, diwajibkannya uji coba HIV tanpa mendapat persetujuan terlebih dahulu atau perlindungan kerahasiaannya, dan penerapan karantina terhadap orangorang yang terinfeksi HIV (UNAIDS : 2006).

Kekerasan atau ketakutan atas kekerasan yang dirasakan oleh para penderita HIV/AIDS, telah mencegah banyak orang untuk melakukan tes HIV, memeriksa bagaimana hasil tes mereka, atau berusaha untuk memperoleh perawatan, sehingga mungkin mengubah suatu sakit kronis yang dapat dikendalikan menjadi "hukuman mati" dan menjadikan meluasnya penyebaran HIV AIDS.
Menurut Herek GM (2002), stigma HIV AIDS lebih jauh dapat dibagi menjadi tiga kategori, yaitu :

1) Stigma instrumental, yaitu refleksi ketakutan dan keprihatinan atas hal-hal yang berhubungan dengan penyakit mematikan dan menular.

2) Stigma simbolis, yaitu penggunaan HIV AIDS untuk mengekspresikan sikap terhadap kelompok sosial atau gaya hidup tertentu yang dianggap berhubungan dengan penyakit tersebut.

3) Stigma kesopanan, yaitu hukuman sosial atas orang yang berhubungan dengan isu HIV AIDS atau orang yang positif HIV. Stigma AIDS sering diekspresikan dalam satu atau lebih stigma, terutama yang berhubungan dengan homoseksualitas, biseksualitas, pelacuran, dan penggunaan narkoba melalui suntikan. Banyak negara maju, terdapat penghubungan antara AIDS dengan homoseksualitas atau biseksualitas, yang berkorelasi dengan tingkat prasangka seksual yang lebih tinggi, misalnya sikap-sikap anti homoseksual. Demikian pula terdapat anggapan adanya hubungan antara AIDS dengan hubungan seksual antar laki-laki, termasuk bila hubungan terjadi antara pasangan yang belum terinfeksi.

Kemensos (2011) menyatakan, seseorang yang terjangkit HIV AIDS dapat berdampak sangat luas dalam hubungan sosial, dengan keluarga, hubungan dengan teman-teman, relasi dan jaringan kerja akan berubah baik kuantitas maupun kualitas. Orang-orang yang terjangkit HIV AIDS secara alamiah hubungan sosialnya akan berubah.

Analisa pengaruh program Social Enterpreneurship kelompok ODHA terhadap Stigma Masyarakat tentang HIV/AIDS di daerah Binaan KPA Kota Kediri

Pengaruh Program Sosial Enterpreneurship pada ODHA terhadap Stigma Masyarakat tentang HIV/AIDS dilakukan menggunakan uji Chi Square 
dengan $\alpha 0,05$. Dari hasil uji didapatkan $\alpha$ $0,00$ ( $\leq \alpha \quad 0,05)$ artinya ada pengaruh program Sosial Enterpreneurship terhadap Stigma masyarakat tentang HIV/AIDS (hasil uji terlampir). Kegiatan social entrepreneurship yang berhasil dilaksanakan dengan baik, akan memperbaiki cap buruk atau stigma yang diberikan oleh masyarakat. Begitupun sebaliknya, jika ODHA tidak memiliki kegiatan social entrepreneurship akan meningkatkan persepsi buruk masyarakat tentang HIV/AIDS yang dirasakan oleh para ODHA. Hal ini dapat dijelaskan sbb:

Orang-orang yang terjangkit HIV AIDS secara alamiah hubungan sosialnya akan berubah. Dampak yang paling berat dirasakan oleh keluarga dan orang-orang dekat lainnya. Perubahan hubungan sosial dapat berpengaruh positif atau negatif pada setiap orang. Reaksi masing-masing orang berbeda, tergantung sampai sejauh mana perasaan dekat atau jauh, suka dan tidak suka seseorang terhadap yang bersangkutan. Upaya kuratif pada aspek sosial harus diterapkan kepada pengidap HIV AIDS, hal itu dengan melihat bahwa pengidap HIV AIDS mengalami proses "labelling" oleh masyarakat dimana mereka mendapatkan label buruk sebagai "orang-orang yang tidak berguna". Upaya kuratif pada aspek sosial difokuskan dalam upaya mendorong pengidap HIV AIDS agar menjadi produktif dan punya kontribusi terhadap masyarakat, maka secara tidak langsung akan mengurangi stigma buruk di masyarakat.

Selain hal-hal seperti yang disebutkan di atas, ada hal lain yang perlu diperhatikan akibat dari kurangnya pengetahuan dan pemahaman terhadap penyakit HIV AIDS, kebanyakan masyarakat berasumsi ODHA itu berbahaya, pembawa sial, orang hina, tidak berguna, dan segala caci maki yang menusuk hati. Oleh karena itu, sangat perlu sosialisai tentang penyakit HIV AIDS pada masyarakat umum, terutama pada masyarakat desa.
Sosialisasi itu perlu agar masyarakat bisa sadar dari persepsi buruk mereka terhadap ODHA, dan yang terpenting adalah menghindari perilaku-perilaku yang bisa menyebarluaskan epidemi HIV AIDS terhadap masyarakat luas.

Nursalam (2005) menjelaskan bahwa seorang penderita HIV AIDS setidaknya membutuhkan bentuk dukungan dari lingkungan sosialnya. Dimensi dukungan sosial meliputi tiga hal, yaitu : 1) Emotional support, meliputi perasaan nyaman, dihargai, dicintai, dan diperhatikan. 2) Cognitive support, meliputi informasi, pengetahuan dan nasehat. 3) Materials support, meliputi bantuan atau pelayanan berupa sesuatu barang dalam mengatasi suatu masalah.

Orang yang hidup dengan HIV dan AIDS (ODHA) termasuk di antara kelompok-kelompok yang paling rentan dalam masyarakat Indonesia. Stigmatisasi sosial akibat tidak adanya pemahaman sehubungan dengan risiko penularan dari orang yang terinfeksi menyebabkan banyak ODHA kehilangan pekerjaan mereka atau tidak dapat memperoleh pekerjaan untuk menafkahi diri mereka sendiri maupun keluarganya. Banyak ODHA menanggulangi masalah ini dengan berusaha bekerja di sector informal, sering kali dengan mulai membuka usaha mikro atau usaha kecil. Oleh sebab itu, memberikan bantuan untuk mewujudkan terbentuknya usahausaha seperti itu oleh ODHA dan keluarganya merupakan strategi yang berharga. Untuk mengurangi beban yang dihadapi oleh orang-orang yang terinfeksi HIV dan anggota rumah tangga mereka (ILO, 2009)

\section{Kesimpulan}

Jenis Kegiatan yang paling banyak dijalankan oleh ODHA di Kota Kediri adalah Sektor Wiraswasta. Hampir seluruh ODHA mempersepsikan adanya Stigma dari masyarakat tentang HIV/AIDS 
Program Sosial Enterpreneurship berpengaruh terhadap Stigma Masyarakat tentang HIV/AIDS

\section{Saran}

\section{Untuk Tempat Penelitian}

Mengacu pada hasil penelitian ini maka perlu kiranya dilakukan hal-hal sebagai berikut:

1. Perlunya memberikan Emotional support, meliputi perasaan nyaman, dihargai, dicintai, dan diperhatikan melalui peningkatan partisipasi aktif para ODHA dalam kegiatan kelompok pendukung sebaya. Perlu dilakukan konseling pada ODHA untuk penguatan mental spiritual, dan konseling pada keluarga ODHA dan masyarakat agar dapat memberikan dukungan pada ODHA secara konstruktif

2. Perlunya peningkatan Cognitive support. Melalui penyebarluasan informasi tentang HIV /AIDS ,peningkatan pengetahuan melalui upaya pelatihanpelatihan dan penguatan psikologis para ODHA melalui kerjasama dengan pihak yang terkait. Melakukan pendidikan pada masyarakat untuk mengurangi stigma dan diskriminasi, membangun dan mengembangkan sebanyak mungkin dukungan sosial baik dari komunitas ODHA sendiri maupun di luar ODHA.

3. Pemberian Materials support, meliputi bantuan atau pelayanan berupa peningkatan pelayanan VCT, dan pemberdayaan masyarakat untuk meningkatkan kemandirian para ODHA. Perlu pengembangan program rekreasional, dan pengembangan potensi ODHA terutama pemberdayaan ekonomi, pemanfaatan pengalam hidup sebagai penderita HIV/AIDS untuk mensupport orang-orang yang senasib

\section{Untuk Penelitian Selanjutnya}

Perlu dikembangkan penelitian yang lebih komprehensif dengan melibatkan beberapa pihak yang terlibat misalnya mengevaluasi dampak
HIV/AIDS terhadap Psikologis dan ekonomi para ODHA

\section{Daftar Pustaka}

Bappeda Kota Kediri, 2013. LAKIP Kota Kediri.

Depkes, RI. 2003. Buku Pedoman Nasional Perawatan, Dukungan, dan pengobatan bagi ODHA. Buku Pegangan bagi Petugas Kesehatan dan Petugas Lainnya. Jakarta

Depkes, RI. 2009. Sehat dan Positif untuk ODHA. Jakarta

Depkes, RI. 2010. Pedoman Pelaksanaan Kewaspadaan Universal di Pelayanan Kesehatan. Jakarta

KPA Nasional, 2010. Pedoman Pencegahan HIV melalui Transmisi Seksual. Jakarta

M. Zainuddin, 2000. Metodologi Penelitian. Surabaya

Nursalam. (2003) Konsep Penerapan Metodologi Penelitian Ilmu Keperawatan. Salemba Medika, Jakarta.

Nursalam. (2008) Konsep dan Penerapan Metodologi Penelitian Ilmu keperawatan (Edisi 2). Salemba Medika, Jakarta

Pusdiklatnakes Kemenkes, RI. 2013. Modul Pelatihan Managemen HIV/AIDS bagi Tenaga Pendidik. UPT Pelatihan Kesehatan Masyarakat Murnajati

Richard, Muma. 2000.HIV Manual Untuk Tenaga Kesehatan. EGC: Jakarta

Ronald Hutapea, 2003. AIDS\& PMS dan Perkosaan. Rineke Cipta: Jakarta

Soekidjo Notoatmodjo. (2005). Metodologi Penelitian Kesehatan. Rineka Cipta, Jakarta

Sugiyono. (2006). Statistika untuk Penelitian. Alfabeta, Bandung

World Bank. 2009. HIV and AIDS in South Asia: An Economic Development Risk. World Bank. Washington, DC 